\title{
PENDIDIKAN KARAKTER MELALUI PEMBIASAAN RUTIN UNTUK MENANAMKAN NILAI - NILAI PENDIDIKAN ISLAM PADA SISWA SD/MI
}

\author{
${ }^{1)}$ Ninik Hidayati, Institut Agama Islam Nahdlatul Ulama Tuban, \\ Email : hidayatininik@gmail.com \\ ${ }^{2)}$ Nurul Hakim, Institut Agama Islam Nahdlatul Ulama Tuban, \\ Email: nurulhakim@stitmatuban.ac.id \\ ${ }^{3)}$ M. Zakki Sulton, Institut Agama Islam Nahdlatul Ulama Tuban, \\ Email : zakkisulton082@gmail.com
}

\begin{abstract}
Islamic Education Values through the habituation program in SD / MI. The theories used as a foundation in this research include the theory of character education, routine habituation, and the values of Islamic education.

Based on the background of the problem, this research is expected to provide answers to the problem formulation (1). How is the implementation of character education through routine habituation to instill the values of Islamic education in SD / MI students?, (2). How are the effectiveness and benefits of implementing routine habituation to instill the values of Islamic education in SD / MI students?

Based on the formulation of the problem, this study aims to (1). To find out the implementation of character education through routine habituation to instill the values of Islamic education in SD / MI students. (2). This is to determine the level of effectiveness and benefits of routine habituation to instill the values of Islamic education in schools in SD / MI students.
\end{abstract}

Keywords: Character education, routine habituation, Islamic education values

\section{Pendahuluan}

Dunia pendidikan kini menjadi pusat sorotan dan perhatian utama sebagai satu bentuk lembaga pendidikan yang menjalankan sistem dan proses pendidikan, namun apakah dunia pendidikan kita sampai hari ini dapat di katakan berhasil? Ini merupakan satu tanda tanya besar buat kita semua sebagai penanggung jawab terhadap kemajuan dan perkembangan pendidikan. Indonesia saat ini bisa dikatakan krisis moral, karena apa ? Berbagai macam masalah yang terjadi di bangsa ini diantarannya terjadinya tawuran antar pelajar, tawuran antar mahasiswa, penyalahgunaan narkoba dan obat-obatan terlarang, pergaulan bebas antar pelajar, tindakan kekerasan peserta didik senior terhadap juniornya, kekerasan dalam rumah tangga, menjamurnya 
perbuatan korupsi di kalangan pejabat, kurangnya rasa hormat terhadap orang tua dan guru, dan berbagai tindakan kriminal lainnya, semua itu mengindikasikan telah tergusurnya nilai-nilai luhur keagamaan dari bangsa ini, jika dibiarkan hal ini akan menghantarkan bangsa ini menuju kehancuran. Itulah yang menjadikan agama di Indonesia kini telah kehilangan etikanya, dan dalam konteks pendidikan, pendidikan telah hilang karakternya.Kita dapat mengamati sendiri betapa banyaknya penyimpangan yang dilakukan oleh pelajar, sedangkan disisi lain Indonesia saat ini memerlukan sumberdaya manusia dalam jumlah dan mutu yang memadai sebagai pendukung utama dalam pembangunan.Untuk memenuhi sumberdaya manusia tersebut, pendidikan memiliki peran yang sangat penting. Hal ini sesuai dengan UU No 20 Tahun 2003 Tentang Sistem Pendidikan Nasional Pada pasal 3 yang menyebutkan bahwa pendidikan nasional bertujuan mengembangkan kemampuan dan membentuk karakter serta peradaban bangsa yang bermartabat dalam rangka mencerdaskan kehidupan bangsa. Berdasarkan fungsi dan tujuan pendidikan tersebut maka bisa dikaitkan dengan pembentukan karakter peserta didik sehingga mampu bersaing, beretika, bermoral, sopan dan santun dalam berinteraksi dengan masyarakat. Dengan adanya karakter siswa yang memiliki sikap tersebut maka siswa tidak hanya mengerti akan pengetahuannya (kognitif) saja, akan tetapi siswa mampu mengimbangi dengan moral dan akhlaq yang baik. Sebab kesuksesan seorang tidak ditentukan semata-mata oleh pengetahuan dan kemampuan teknis (hard skill) saja, tetapi lebih dominan dalam kemampuan mengelola diri dan orang lain (soft skill). ${ }^{1}$

Pendidikan karakter di era globalisasi sekarang ini memiliki peran yang sangat penting bagi setiap individu khususnya peserta didik agar menjadi manusia yang beradab yang diharapkan oleh masyarakat, bangsa, dan negara. Sedemikian seriusnya persoalan itu, hingga presiden dan para menteri, lebih khusus menteri agama dan menteri pendidikan dalam berbagai kesempatan menyerukan hal itu. Pendidikan karakter oleh banyak kalangan dipandang sangat mendesak dilakukan bersama. $^{2}$

Pendidikan karakter merupakan usaha sadar dan terencana untuk mewujudkan suasana belajar dan proses pembelajaran agar peserta didik secara aktif mengembangkan potensi dirinya untuk memiliki kepribadian, akhlak mulia, dan budi pekerti sehingga karakter terbentuk dan menjadi

\footnotetext{
${ }^{1}$ Darajat, Zakiyah. (2004). Ilmu Pendidikan Islam,Cet. V. Jakarta: Bumi Aksara.

${ }^{2}$ Frey. (2002). Pendidikan Karakter. Jakarta: Rineka Cipta.
} 
ciri khas peserta didik. Hampir semua orang dikenai pendidikan dan melaksanakan pendidikan. ${ }^{3}$ Sebab pendidikan tidak pernah terpisah dengan kehidupan manusia. Anak-anak menerima pendidikan dari orang tuanya dan manakala anak-anak ini sudah dewasa dan berkeluarga mereka juga akan mendidik anak-anaknya. Begitu pula di sekolah dan perguruan tinggi, peserta didik dan dididik oleh dosen. Pendidikan adalah khas milik dan alat manusia. Tidak ada makhluk lain yang membutuhkan pendidikan.Makna pendidikan secara sederhana dapat diartikan sebagai usaha manusia untuk membina kepribadiannya. sesuai dengan nilai-nilai di dalam masyarakat dan kebudayaan. Bagaimanapun sederhananya peradaban suatu masyarakat, di dalamnya terjadi atau berlangsung suatu proses pendidikan. Karena itulah sering dinyatakan pendidikan telah ada sepanjang peradaban umat manusia.

Peningkatan mutu pendidikan merupakan salah satu program pendidikan nasional yang dirancang dengan sangat baik oleh pemerintah, hal ini disebabkan oleh terjadinya krisis yang cukup serius dalam bidang pendidikan. Krisis dalam bidang pendidikan tidak hanya disebabkan oleh kurangnya anggaran pemerintah dalam membiayai kebutuhan pokok pendidikan namun juga kurangnya tenaga ahli dalam bidang pendidikan. Penyelenggaraan pendidikan salah satunya adalah melalui jalur pendidikan sekolah. Dalam keseluruhan proses pendidikan di sekolah kegiatan belajar mengajar merupakan kegiatan yang paling pokok, disamping itu guru dituntut untuk tidak hanya mengajar tetapi guru juga harus mendidik siswa. ${ }^{4}$

Oleh karena itu, sebagai calon guru kita di tuntut untuk membantu siswa, agar supaya dalam hal belajar mengajar siswa dapat memahami setiap apa yang sedang di ajarkan, khususnya pembelajaran tentang pendidikan agama islam.Agar pembelajaran berjalan efektif dan efesien maka dalam proses belajar mengajar harusnya guru menerapkan beberapa metode pembelajaran. Dalam hal mengajar ada beberapa metode yang biasa di pakai, salah satu antaranya adalah metode pembiasaan. Pembiasaan melakukan hal yang positif pada anak usia dini dapat membantu supaya anak menjadi insan yang sopan dan santun, baik dalam lingkungan sekolah, lingkungan keluarga dan lingkungan masyarakat.

Dari artikel ini rumusan masalahnya adalah: 1)Bagaimana pelaksanaan pendidikan karakter melalui pembiasaan rutin untuk menanamkan nilai-nilai pendidikan Islam pada siswa SD/MI?;

\footnotetext{
${ }^{3}$ D. Marimba Ahmad. (1989). Pengantar Filsafat Pendidikan. Bandung : Al Ma'arif.

${ }^{4}$ Arif, Much Machfud \& Rr. Kusuma Dwi Ma;rifati. (2019). Implementasi Strategi Pembelajaran kontekstual Di MI (Madrasah Ibtidaiyah). Jurnal Premiere IAINU Tuban
} 
serta 2)Bagaimana efektivitas dan manfaat penerapan pembiasaan rutin untuk menanamkan nilainilai pendidikan Islampada siswa SD/MI? Sedangkan tujuan riset ini adalah : 1)Untuk mengetahui pelaksanaan Pendidikan karakter melalui pembiasaan rutin untuk menanamkan nilainilai pendidikan Islam pada siswa SD/MI; dan 2)Untuk mengetahui tingkat efektivitas dan manfaat dari pembiasaan rutin untuk menanamkan nilai-nilai pendidikan Islam di sekolah pada siswa SD/MI.

\section{Metodologi}

Penelitian ini menggunakan metode observasi, wawancara, dan dokumentasi. Jenis penelitian yang digunakan dalam penelitian ini adalah penelitian kualitatif deskriptif. Subjek penelitian ini adalah peserta didik SD/MI sebagai responden. Instrument penelitian yang digunakan dalam penelitian ini adalah lembar wawancara dan lembar dokumentasi berupa dokumen pendukung bahan skripsi yaitu foto kegiatan. Penelitian ini bersifat kualitatif dengan mengeksplorasi data yang ada di lapangan terkait permasalahan yang telah dirumuskan dengan metode analisis deskriptif yang bertujuan memberikan uraian secara tepat tentang penerapan metode pembiasaan untuk menanamkan nilai-nilai pendidikan Islam di SD/MI.Penelitian ini bersifat kualitatif dengan mengeksplorasi data yang ada di lapangan terkait permasalahan yang telah dirumuskan dengan metode analisis deskriptif yang bertujuan memberikan uraian secara tepat tentang penerapan metode pembiasaan untuk menanamkan nilai-nilai pendidikan Islam di SD/MI. Sugiyono mendefenisikan metode kualitatif adalah metode yang berlandaskan ada filsafat postpositivisme, digunakan untuk meneliti pada kondisi obyek yang alamiyah, (sebagai lawanya adalah eksperimen) dimana peneliti adalah sebagai instrumen kunci. $^{5}$

\section{Hasil}

Hasil dan pembahasan dalam penelitian kualitatif agak sulit untuk dibedakan dan dipisahkan, karena sifat dari informasi yang diperoleh, maka bagian hasil dan bagian pembahasan disatukan. Dalam hal ini akan membahas temuan dari penelitian lapangan yang berkaitan dengan bagaimana penerapan pembiasaan rutin dalam menanamkan pendidikan Islam pada siswa SD/MI. Analisis pada bagian ini didasarkan pada informasi kualitatif dengan pendekatan analisis

\footnotetext{
${ }^{5}$ Sugiyono. (2010). Metode Penelitian Pendekatan Kuantitatif, Kualitatif dan R\&D. Bandung: Alfabeta
} 
deskriptif . Dalam penelitian ini menggunakan dua tahapan analisis data yaitu pertama adalah reduksi data dan yang kedua triangulasi data, dimana penelitian dimulai dengan memahami situasi di lapangan melalui sumber daya manusia yang terlibat dalam satuan pendidikan. Penelitian ini menyajikan dan memaparkan deskripsi umum tentang pengelolaan Pendidikan Karakter di SDN Sambonggede 1 dan di Mi Islamiyah Sumberjo sebagai Sekolah yang sudah melaksanakan Pendidikan Karakter di Kecamatan Merakurak. Hasil pembahasan penelitian ini dilengkapi dengan berbagai data yang diperoleh dari pengelolaan pendidikan karakter yang telah dimplementasikan. Hasil-hasil penelitian ini diperoleh melalui pelaksanaan rintisan (piloting) yang dilakukan di SDN Sambonggede 1 dan di Mi Islamiyah Sumberjo. Subjek dari penelitian ini terdiri dari tim pengembang pendidikan karakter di SD Sambonggede 1 dan di MI Islamiyah Sumberjo, yaitu Kepala Sekolah sebagai penanggung jawab, diambil juga guru dari berbagai mata pelajaran serta orang tenaga administrasi sekolah dan beberapa peserta didik. Implementasi pendidikan karakter yang tercakup dalam pendidikan budaya dan karakter yang telah dilaksanakan dalam nilai religius, disiplin, kreatif, peduli lingkungan ini secara lengkap terlampir pada lampiran peta perkembangan deskripsi kondisi awal satuan pendidikan rintisan pelaksanaan pendidikan karakter dan Rencana aksi implementasi pendidikan karakter yang tercakup dalam pendidikan budaya dan karakter yang telah dilaksanakan dalam nilai religius, disiplin, kreatif, peduli lingkungan. Pelaksanaan pendidikan karakter di sekolah piloting di SDN Sambonggede 1 dan di Mi Islamiyah Sumberjo merupakan agenda yang direncanakan dan disiapkan secara matang yang dicantumkan dalam Kurikulum 13 (K13) sekolah penyelenggara.

SDN Sambonggede 1 dan di Mi Islamiyah Sumberjo sebagai sekolah piloting pendidikan karakter jenjang sekolah dasar di Kecamatan Merakurak yang menerapkan Kurikulum 13 serta mengembangkan sendiri nilai-nilai pendidikan karakter berdasarkan acuan yang disiapkan secara nasional dan mengintegrasikan di dalamnya nilai-nilai pembentuk karakter yang dimaksudkan. Sejak awal tahun dilaksanakannya hingga sekarang, dalam pelaksanaa pendidikan karakter yang dimaksudkan sekolah piloting terlebih dahulu harus mempersiapkan perencanaan, kemudian baru melakukan atau melaksanakan pendidikan karakter, setelah itu baru melakukan evaluasi terhadap program dan hasil pelaksanaan pendidikan karakter tersebut. Peneliti melakukan wawancara, melakukan observasi dan mengambil dokumentasi untuk mengetahui pembiasaan yang dilakukan kepala sekolah MI Islamiyah Sumberjo Merakurak. 
Peneliti melakukan wawancara dengan Kepala Sekolah, yaitu Bapak Nurul Huda, S.Pd.I dalam kaitannya dengan penerapan pembiasaan rutin yang dilakukan oleh sekolah, responden menyatakan bahwa:

"Pembiasaan yang sudah dilaksanakan pada siswa Madrasah Ibtidaiyah Islamiyah merupakan kebiasaaan yang sudah diterapkan kepada seluruh siwa oleh guru di sekolah, penerapan pembiasaan dengan mengamalkan nilai-nilai Islam suatu hal yang menjadi visi dan misi sekolah karena dengan metode pembiasaan ini berdampak positif pada siswa untuk membangun karakter Islami sejak dini."

Berikut ini adalah pembiasaan yang diterapkan di MI Islamiyah Sumberjo Kecamatan Merakurak Kabupaten Tuban:

\section{Membiasakan Budaya Salam}

Sebagai mana yang di kemukakan oleh Bapak Nurul Huda, S.Pd.I selaku kepala Madrasah Ibtidaiyah Islamiyah pada saat diwawancarai di ruang guru pada Selasa pagi tanggal 10 Maret 2020 pukul 08.30 beliau mengatakan bahwa:

"Pembiasaan itu di lakukan oleh siswa dari pagi hari sejak siswa dan guru datang sekolah sampai pulang sekolah, agar siswa dan guru bisa membiasakan diri disiplin, sopan dan santun baik dalam lingkungan sekolah maupun di luar sekolah. Seperti memberi salam saling sapa, baik itu di pagi hari ketika datang ke sekolah maupun pulang sekolah atau berpapasan di jalan dengan mengucapkan salam."

Salah satu contoh kecil pembiasaan yang di terapkan di madrasah yang berdampak baik pada akhlak siswa di antaranya memberi salam saat hendak masuk kelas, memberi salam ketika berpapasan dengan guru baik dalam lingkungan sekolah ataupun di luar sekolah. Dengan adanya pembiasaan memberi salam kepada guru setiap hari maka siswa secara otomatis akan melakukan pembiasaan tersebut sampai kelak dewasa.

\section{Sholat Dhuha Bersama}

Kegiatan ini rutin dilaksanakan oleh siswa mulai kelas I sampai kelas VI sebagai langkah awal dimulainya proses pembelajaran di kelas. Pembiasaan ini dipantau sendiri oleh wali kelas masing-masing untuk melihat dan mendampingi siswa yang akan melakukan sholat Dhuha tersebut. Pelaksanaan sholat bersama di madrasah Islamiyah ini dilaksanakan di Masjid depan 
Sekolah. Untuk kelas 1 masih sangat butuh pendampingan dari wali kelas yaitu Ibu Luluk Itsna, S.Pd.I, beliau mengatakan bahwa pendampingan tersebut mulai dari mengambil air wudlu, gerakan serta do'a dalam sholat. Seperti yang dikatakan Beliau saat wawancara di ruang guru kemarin bahwa:

“Ketika jam masuk telah berbunyi anak-anak langsung berbaris dan berdo'a seperti biasa setelah do'a anak-anak langsung membawa mukenah (bagi perempuan) dan sajadah langsung meletakkan di Masjid. Setelah itu anak-anak bergegas mengambil air wudlu. Nah, disitulah peran guru pendamping sangat dibutuhkan guna memantau gerakan anak dalam berwudlu, seaindainya ada yang kurang tepat maka guru secara otomatis akan menegur dan memberikan arahan kepada siswa. Jadi anak-anak paham betul mana anggota tubuh yang harus dialiri air dan bagaimana tata cara berwudlu yang benar."

Demikian ini adalah pernyataan dari Walas kelas 1 yang peneliti wawancari kemarin. Pendapat di atas dibenarkan oleh salah satu orangtua/wali, M. Sholeh menyatakan bahwa:

"Pembiasaan di sekolah dengan sholat berjamaah di pagi hari (Sholat Dhuha) sangat membantu orangtua dalam mendidik anak dalam hal pendidikan agamanya. Sebagai orangtua sangat terbantu dengan diadakannya pembiasaan yang diterapkan di sekolah. Dengan adanya pembiasaan tersebut maka siswa dapat mengaplikasikan di rumah. Dan lagi pembiasaan yang dilakukan di sekolah sangat membantu sholat lima waktunya anak-anak karena sudah terbiasa di ajarkan di sekolah.”

\section{Berbaris dan Do'a Sebelum Masuk Kelas}

Dilanjutkan dengan pembiasaan yang ke-tiga adalah Baris dan berdo'a sebelum masuk kelas. Pembiasaan ini setiap pagi dilakukan siswa MI Islamiyah sebagai rutinitas sehari hari sebelum anak-anak memulai pembelajaan, adapun yang memimpin dalam kegiatan tersebut adalah ketua kelas.

Lebih lanjut terkait kegiatan tersebut kami mewawancarai Kepala Madrasah, yakni Bapak Nurul Huda, S.Pd.I beliau mengatakan bahwa :

"Dengan adanya kegiatan ini diharapkan siswa mampu menerapkan pembiasaan tersebut dalam kehidupan sehari hari, karena apa berdo'a sebelum pembelajaran 
tersebut nantinya akan memberikan dampak yang positif pada anak yaitu diantaranya adalah menumbuhkan nilai spiritual peserta didik serta dapat sangat berpengaruh dalam penanaman pendidikan agama Islam pada dunia pendidikan.”

Lanjut pernyataan orangtua/wali peserta didik Listiyono menyatakan bahwa:

"Sebagai orang tua/wali peserta didik bentuk penanaman nilai-nilai Pendidikan Islam yang dilakukan pihak sekolah sangat membantu karena anak-anak lebih memiliki kebiasaan yang religius."

Lanjut pernyataan orangtua/wali peserta didik Khusnul menyatakan bahwa:

"Dengan adanya penanaman nilai-nilai Islam saya berharap bahwa anak-anak dapat menerapkan dengan baik agar menjadi bekal dikemudian hari.”

\section{Berdiri ketika Guru Datang dan Menggucap Salam (Bentuk Penghormatan)}

Pembiasaan ini pertama kali diajarkan Oleh Bapak Ahmad Irchamni, S.Pd.I selaku guru Agama di madrasah ini. Beliau adalah Kyai dan memiliki Ponpes di Desa Sambonggede Kecamatan Merakurak, Beliau mengkaji ilmu-ilmu agama bertahun tahun di Pondok Pesantren Sarang yang ada di Jawa Tengah.

Pembiasaan yang awalnya diterapkan oleh beliau pada siswa kelas atas tersebut sekarang diterapkan juga di kelas bawah. Seperti halnya yang diucapkan beliau ketika wawancara kemarin, beliau mengatakan bahwa :

"Kegiatan penghormatan tersebut kami jadikan pembasaan rutin pada siswa, karena apa dengan adanya kegiatan seperti itu siswa dapat terbiasa menghormati orang yang sepantasnya dihormati seperti Orang tua, Guru, Famili dan orang yang lebih tua darinya. Pembiasaan ini kami sengaja terapkan guna melatih anak-anak dalam membentuk karakter dan membelajarkan Akhlaqul karimah agar kelak menjadi suatu identitas atau wawasan agama yang sudah menjadi kebiasaan dalam bermasyarakat.” Lanjut dengan pendapat dari siswa Muhammad Syarif Ilham kelas VI yang kami wawancarai kemarin dia Mengatakan bahwa :

"Kebiasaan hormat (Ta'dzim) terhadap Bapak / Ibu Guru ini sudah saya dan temanteman lakukan setiap hari ketika Bapak / Ibu Guru datang dan mengucap salam.” 
Terkait hal tersebut Orangtua/wali murid yang bernama Pak wiyanto berpendapat bahwa : "Beliau sangat mendukung dan senang dengan adanya pembiasaan yang bernuansa ala santri tersebut, karena dengan begitu siswa sudah di didik untuk menghormati orang lain apalagi dengan gurunya dan saya sangat mendukung hal tersebut dijadikan pembiasaan rutin pada madrasah ini. Semoga madrasah ini menjadi lebih baik dan selalu mencetak generasi-generasi yang memiliki kepribadian yang baik."

Dilanjutkan mwawancarai wali murid kelas III yang dalam hal ini dikatakan oleh Ibu Masriyati yaitu :

"Sebagai orangtua/wali peserta didik bentuk penanaman nilai-nilai Islam yang dilakukan pihak sekolah sangat membantu karena anak-anak lebih belajar menghormati orangtua."

Pendapat dari salah seorang guru Kelas VI Ibu Sulis, S.Pd. beliau mengungkapkan bahwa : "Kendala yang sering dihadapi dalam penanaman nilai-nilai Islam di sekolah ketika ada beberapa peserta didik yang masih perlu dorongan untuk semangat melakukan pembiasaan tersebut, tapi hal itu tidak menyurutkan semangat kami dalam melaksanakan pembiasaan itu secara rutin, serta banyak dorongan dari wali murid.”

\section{Pembacaan Asmaul Husna Secara Bersama (Tanpa Teks)}

Pembiasaan ini dilakukan setiap hari Sesudah berdo'a, pembacaan Asmaul Husna dimasingmasing kelas ini dibaca dan dilagukan secara serentak oleh para siswa, sehingga pembacaan tersebut terbaca secara rapid an indah. Dengan dibacanya Asmaul Husna tersebut diharapkan siswa akan hafal secara bersama dan termasuk dalam rangka mengagungkan Allah SWT.

Lebih lanjut peneliti melakukan wawancara kepada Ibu Rohmatul Ummah, S.Pd beliau mengatakan bahwa :

"Pembacaan Asmaul Husna ini sudah menjadi progam Madrasah, diharapkan seusia yang masih sangat cemerlang ini sebisa mungkin pihak Madrasah mendidik anak supaya hafal dengan bacaan-bacaan yang sangat erat kaitannya dengan pendidikan Islam. Oleh karena itu pihak Madrasah sangat menekankan pembiasaan-pembiasaan rutin untuk membiasakan anak agar memiliki pengetahuan yang religius."

Dilanjutkan pernyataan dari seorang wali murid yaitu ibu Hindun beliau berpendapat bahwa : 
"Jadi kegiatan ini sudah berlangsung lama sejak anak saya kelas 1, jadi masuk sekolah berdo'a setelah itu bersama-sama membaca Asmaul Husna setelah itu baru pembelajaran dimulai"

\section{Progam Tahfidz}

Pembiasaan Tahfidz atau disebut dengan hafalan ini di laksanakan oleh pihak madrasah guna mendidik anak sejak dini untuk menumbuhkan generasi yang cinta terhadap Al-Qur'an, Mencetak generasi-generasi Qur'ani yang berwawasan luas dan serta dapat dijadikan sebagai progam andalan madrasah. Karena pada siswa se-usia SD/MI ini sangatlah cocok untuk dijadikan pondasi awal pada progam tahfidz ini.

Lebih lanjut terkait pembiasaan Tahfidz ini kami mewawancarai seorang guru yaitu Bapak Imam Syarif Hidayatullah, S.Pd.I beliau adalah guru Agama dan beliau juga mengikuti progam dari Ustadz Yusuf Mansur yang bernama "Rumah Tahfidz" berikut hasil wawancara kami kepada beliau:

"Beliau mengatakan bahwa progam Tahfidz ini sudah kami laksanakan lama, kegiatan ini kami khususkan untuk kelas atas yaitu kelas IV,V, dan VI untuk kelas bawah masih hafalan Surat-surat pendek dan itu dihandel langsung oleh wali kelasnya masing-masing. Hafalan ini mulai dari juz 30 sampai 28 untuk kelas Vi yang sudah persiapan wisuda biasanya kami juga melaksanakan wisuda Tahfidz bebarengan dengan wisuda madrasah. Untuk kendalanya dari progam ini adalah masih adanya siswa yang terlambat menghafal dari temannya, tetapi itu tidak menjadi masalah besar bagi kami, kami tetap mendampingi secara rutin dalam pembiasaan ini."

Dilanjutkan pernyataan dari Kepala Madrasah bahwa Progam ini adalah progam andalan bagi madrasah kami karena apa khususnya di Kecamatan Merakurak ini yang melaksanakan progam ini hanya madrasah kami. Dengan adanya progam ini diharapkan anak mendapatkan bekal untuk melanjutkan hafalan pada sekolah ditingkat yang lebih tinggi karena sekolah-sekolah favorit sekarang sangat dibutuhkanskill yang bukan hanya dari sisi akademik melainkan siswa harus memiliki skill lain untuk menunjang tantangan di era sekarang ini. 


\section{Sholat Dzuhur Berjama'ah}

Kegiatan sholat Dzuhur berjama'ah ini suatu kewajiban bagi seluruh siswa untuk melatih kedisiplinan siswa dalam melakukan kewajiban sebagai seorang Muslim. Diharapkan siswa akan terbiasa dan melakukan kewajiban tersebut tanpa perintah dulu dari orang tua.

Bapak Nurul Huda, S.P.d.I berpendapat dalam wawancara yang peneliti lakukan adalah sebagai berikut :

“Kegiatan sholat Dzuhur berjama'ah ini suatu kewajiban bagi seluruh siswa kecuali kelas satu dan dua dikarenakan dua kelas tersebut masih perlu pembimbingan yang intensif, disamping itu ada beberapa orang tua yang belum mendukung apabila dua kelas tersebut ikut melaksanakan sholat dzuhur berjama'ah."

Dilanjutkan pernyataan dari Bapak Darminto salah seorang wali Murid kelas VI beliau menyatakan bahwa :

"Alhamdulillah Sekolah sudah menerapkan kegiatan sholat Dzuhur Berjama'ah, dengan adanya kegiatan ini bisa melatih anak untuk sadar akan tanggung jawab disamping tanggung jawab duniawi juga sadar akan tanggung jawab Ukhrawi.”

Bapak Achmad Irchamni, S.Pd.i juga berpendapat yaitu :

Menurut bapak Irchamni, pentingnya dilaksanakannya sholat dhuhur berjamaah untuk membiasakan siswa melaksanakan sholat yang hal ini sesuai dengan sabda Rosulullah SAW. yaitu :

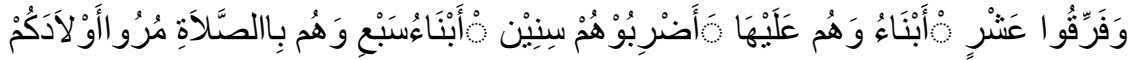

الَْضضَاجِعِ فِي بَيَنَهُمْ هُرْ

Artinya : "Perintahkanlah anak-anak kalian untuk melaksanakan sholat apabila sudah mencapai umur tujuh tahun, dan apabila sudah berumur sepuluh tahun maka pukulah apabila tidak melaksanakannya, dan pisahkanlah mereka dalam tempat tidurnya" (HR. Abu Daud No : 495). Hadits tersebut menekankan bahwa begitu penting pendidikan sholat sejak dini.

Peneliti juga mewawancarai salah satu siswa yaitu Muhammad Alif Fauddin yaitu murid kelas 4 dia mengatakan bahwa :

"Saya dan teman-teman selalu sholat berjama'ah Dzuhur ketika sudah ada bel tanda untuk Sholat berjama'ah berbunyi." 


\section{Pembahasan}

Pengembangan karakter peserta didik di MI Islamiyah dan SDN Sambonggede 1 Kecamatan Merakurak Kabupaten Tuban tersebut diawali dengan menyusun rancangan kegiatan yang membentuk karakter. Adapun rancangan kegiatan dimulai dengan penyusunan visi, misi dan tujuan sekolah, isi kurikulum, pengembangan silabus dan RPP yang berbasis dengan pendidikan karakter.

Adapun langkah-langkah dalam pengembangan karakter antara lain: mengidentifikasi jenis-jenis kegiatan di sekolah yang perlu dikuasai, pengembangan kegiatan, pelaksanaan kegiatan serta pihak-pihak yang terlibat sebagai pendukung terbentuknya karakter peserta didik. Jenis kegiatan yang diterapkan seperti pembiasaan rutin yang akan dilakukan oleh peserta didik pada kegiatan belajar mengajar. Pengembangan kegiatannya melalui proses belajar pembiasaan yang dilakukan oleh guru, serta seluruh warga sekolah. Salah satu yang melatarbelakangi program pendidikan karakter untuk menanamkan nilai-nilai pendidikan Islam di MI Islamiyah dan SDN Sambonggede 1 Kecamatan Merakurak Kabupaten Tuban dilaksanakan adalah dengan pertimbangan bahwa pembentukan karakter pada usia dini sangat penting, karena pada usia dini dianggap anak belum begitu terpengaruh oleh lingkungan yang membetuk karakternya. Pembentukan karakter pada anak usia dini tidak terlalu sulit sebagaimana halnya pembentukan karakter pada orang dewasa, disamping itu, ketika karakter anak sudah terbentuk, maka sulit untuk dipengaruhi oleh pengaruh-pengaruh dari luar.

Pelaksanaan pendidikan karakter di MI Islamiyah dan SDN Sambonggede 1 Kecamatan Merakurak Kabupaten Tuban yang diimplementasikan dalam pembiasaan rutin untuk menanamkan nilai-nilai Pendidikan agama Islam semua komponen telah dilibatkan, baik itu kepala sekolah, guru dan karyawan, pengawas sekolah, komite sekolah dan wali siswa, maupun komponen-komponen pendidikan itu sendiri yaitu isi kurikulum, proses pembelajaran dan penilaian, penanganan dan pengelolaan mata pelajaran, pengelolaan sekolah, pelaksanaan aktifitas atau kegiatan ko-kurikuler, pengembangan sarana dan prasarana, pembiayaan maupun peningkatan etos kerja seluruh warga sekolah.

Pembiasaan rutin yaitu pembiasaan yang dilakukan peserta didik secara terus menerus dan konsisten setiap saat. Misalnya kegiatan upacara bendera setiap hari Senin, salam dan salim di 
depan pintu gerbang sekolah, piket kelas, sholat berjamaah, berdoa sebelum dan sesudah jam pelajaran, berbaris saat masuk kelas dan sebagainya. ${ }^{6}$

Pendekatan pembiasaan sesungguhnya sangat efektif untuk menanamkan nilai-nilai positif ke dalam diri anak didik, baik pada aspek kognitif, afektif dan psikomotorik. Selain itu pendekatan pembiasaan juga dinilai sangat efisien dalam mengubah kebiasaan negatif menjadi positif. Namun demikian pendekatan ini akan jauh dari keberhasilan jika tidak diiringi dengan contoh tauladan yang baik dari si pendidik. ${ }^{7}$

Sedangkan yang dimaksud pembiasaan rutin menurut peneliti dalam penelitian ini adalah kegiatan yang diadakan oleh madrasah secara terus-menerus untuk menanamkannilai-nilai karakter kepada peserta didik di MI Islamiyah dan SDN Sambonggede 1 Kecamatan Merakurak Kabupaten Tuban.

Kegiatan pembiasaan yang diimplementasikan untuk menanamkan nilai-nilai Pendidikan Agama Islam di MI Islamiyah dan SDN Sambonggede 1 Kecamatan Merakurak Kabupaten Tuban penulis dapat merangkum dengan catatan sebagai berikut :

1. Budaya Salam dan Salim (berjabat tangan kepada guru)

2. Berdo'a sebelum pembelajaran dimulai

3. Penghormatan ketika guru datang

4. Hafalan Surat-surat Pendek dan bacaan serta gerakan Sholat

5. Hafalan Do'a Sehari-hari

6. Pembiasaan Sholat Sunnah Dhuha dan Sholat Dzuhur berjamaah

\section{Tahfidz (Hafalan Al-Qur'an)}

Diharapkan dengan diterapkannya progam pembiasaan seperti kegiatan-kegiatan di atas siswa akan memiliki jiwa dan perilaku yang religius. Dengan demikian Pendidikan Islam merupakan upaya membentuk pribadi muslim yang senantiasa mendasarkan hidup, sikap dan tingkah lakunya pada ajaran Islam atau pembinaan moral yang berdasarkan Al-qur'an dan hadits Nabi saw, dengan senantiasa berpedoman pada seluruh aspek kehidupan manusia baik duniawi maupun ukhrawi demi mencapai predikat muttaqin. ${ }^{8}$ Pendidikan karakter dalam satuan pendidikan merupakan aspek penting untuk mengembangkan karakter warga sekolah yang

\footnotetext{
${ }^{6}$ Hariyanto, Muchlas Samani. 2012. Konsep dan Model Pendidikan Karakter. Bandung: Remaja Rosdakarya.

${ }^{7}$ Arief Armai. 2002. Pengantar Ilmu dan Metodologi Pendidikan Islam. Jakarta: Ciputat Press.

${ }^{8}$ Arifin Muhammad. 1993. Ilmu Pendidikan Islam Cet. II. Jakarta: Bumi Aksara.
} 
memilki nilai-nilai yang berhubungan dengan Tuhan Yang Maha Esa, diri sendiri, sesama, lingkungan dan kebangsaan. ${ }^{9}$ Pelaksanaan pendidikan di sekolah dikenal adanya tiga kegiatan pokok kegiatan, yaitu kegiatan intrakurikuler, kokurikuler, dan ekstrakurikuler. Ketiganya merupakan satu kesatuan utuh yang tak terpisahkan dalam upaya mencapai tujuan pendidikan secara keseluruhan pada suatu sekolah. Kegiatan intrakurikuler merupakan kegiatan utama persekolahan yang dilakukan dengan menggunakan jatah waktu yang telah ditentukan dalam struktur program. Kegiatan ini dilakukan guru dan siswa dalam jam-jam pelajaran tiap hari. Kegiatan intrakurikuler ini dilakukan untuk mencapai tujuan minimal setiap mata pelajaran, baik yang tergolong program inti ataupun program khusus. Untuk mencapai tujuan pendidikan karakter diperlukan upaya dari seorang pemimpin baik itu kepala sekolah, guru, karyawan, komite sekolah maupun wali siswa sehingga pengembangan karakter siswa dapat berlangsung secara terus-menerus.

\section{Kesimpulan}

Berdasarkan uraian tersebut di atas sebagai hasil penelitian yang telah dilaksanakan, maka dapat ditarik beberapa kesimpulan sebagai berikut:

1. Pendidikan karakter melalui pembiasaan rutin untuk menanamkan pendidikan Islam pada siswa SD/MI yang dilakukan di MI Islamiyah dan SDN Sambonggede 1 Kecamatan Merakurak Kabupaten Tuban diimplementasikan dengan pembiasaan salam sapa dengan warga sekolah sejak datang ke sekolah dan saat pulang sekolah, membiasakan berdoa sebelum jam pelajaran di mulai dengan hafalan surah-surah pendek yang telah di tentukan setiap harinya secara bergiliran, dan pembiasaan yang lainnya adalah penanaman nilai-nilai keagamaan kepada peserta didik.

2. Bentuk penanaman nilai-nilai pendidikan Islam pada siswa SD/MI yang dilakukan di MI Islamiyah dan SDN Sambonggede 1 Kecamatan Merakurak Kabupaten Tuban dalam hal ini bentuk-bentuk penanaman nilai-nilai Islam pada peserta didik adalah adanya sholat berjamaah di pagi hari 15 menit sebelum masuk (sholat wajib atau sholat sunnah) yang di tentukan oleh pihak sekolah setiap harinya, dzikir bersama, sampai menghafal surah-surah pendek. Penanaman nilainilai pendidikan Islam tersebut bertujuan untuk membangun karakter peserta didik yang lebih Islami.

\footnotetext{
${ }^{9}$ Chabib Thoha HM. 1996. Kapita Selekta Pendidikan Islam. Yogyakarta: Pustaka Pelajar
} 
3. Efektivitas progam pembiasaan untuk menanamkan nilai-nilai pendidikan Islam pada siswa SD/MI yang dilakukan di MI Islamiyah dan SDN Sambonggede 1 Kecamatan Merakurak Kabupate Tuban, dari hasil penelitian tersebut dapat disimpulkan bahwa pembiasaan yang di lakukan dengan bentuk pembiasaan rutin untuk menanamkan nilai-nilai pendidikan Islam kepada peserta didik tersebut sangat efektif karena dapat meningkatkan akhlak peserta didik yang lebih baik lagi terbukti dari hasil wawancara dari berbagai pihak warga sekolah terhadap peserta didik dan orang tua murid puas akan penerapan metode yang dilakukan di sekolahkarena membantu peserta didik dan orang tua peserta didik sekaligus meningkatkan kualitas pendidikan di MI Islamiyah dan SDN Sambonggede 1 Kecamatan Merakurak Kabupaten Tuban lebih baik lagi dengan metode yang di gunakan membangun nilai-nilai Islam dari usia dini.

\section{Daftar Referensi}

Arief, Armai. 2002. Pengantar Ilmu dan Metodologi Pendidikan Islam. Jakarta: Ciputat Press.

Arif, Much Machfud \& Rr. Kusuma Dwi Ma'rifati. (2019). Implementasi Strategi Pembelajaran kontekstual Di MI (Madrasah Ibtidaiyah). Jurnal Premiere IAINU Tuban

Arifin, Muhammad. 1993. Ilmu Pendidikan Islam Cet. II. Jakarta: Bumi Aksara.

Chabib, Thoha HM. 1996. Kapita Selekta Pendidikan Islam. Yogyakarta: Pustaka Pelajar

Darajat, Zakiyah. (2004). Ilmu Pendidikan Islam,Cet. V. Jakarta: Bumi Aksara.

D. Marimba Ahmad. (1989). Pengantar Filsafat Pendidikan. Bandung : Al Ma'arif.

Frey. (2002). Pendidikan Karakter. Jakarta: Rineka Cipta.

Hariyanto, Muchlas Samani. 2012. Konsep dan Model Pendidikan Karakter. Bandung: Remaja Rosdakarya.

Sugiyono. (2010). Metode Penelitian Pendekatan Kuantitatif, Kualitatif dan R\&D. Bandung: Alfabeta. 